\title{
Silage quality of Piata palisadegrass with palm kernel cake
}

\section{Qualidade da silagem de capim-piatã com torta de dendê}

\author{
Rângelis de Sousa Figueredo ${ }^{1}$; Kátia Aparecida de Pinho Costa ${ }^{2 *}$; \\ Patrícia Soares Epifanio ${ }^{3}$; Eduardo da Costa Severiano²; Welma Santos Cruvinel ${ }^{3}$; \\ Tainá Silvestre Moreira ${ }^{4}$; Kátia Cylene Guimarães ${ }^{2}$
}

\begin{abstract}
This study was developed to evaluate silage quality of Piata palisadegrass with palm kernel cake (Elaeis guineensis Jacq.). The experiment was carried out at the Federal Institute of Goiás State, Campus Rio Verde, in a completely randomized design with four treatments and five repetitions. The treatments consisted of Piata palisadegrass ensiled with palm kernel in the levels of $0,5,10$ and $15 \%$ on a natural basis of the Piata palisadegrass. The material was minced, mixed, packed into experimental silos and opened after 60 days of fermentation. The palm kernel cake is an agro-industrial by-product that can enrich the silage, increasing its nutritional value.The addition of palm kernel cake improved the fermentative and bromatological parameters of the silage, increasing the dry matter, crude protein, ether extract, and total digestible nutrients, with a reduction in the fiber fraction, values of $\mathrm{pH}$, ammonia nitrogen, and titratable acidity. The use of palm kernel cake in Piata palisadegrass silage increase the fractions A, B1, B2 and in vitro dry matter digestibility, and decrease the fractions B3 and C. For achieving the best quality silage it is recommended the addition of $15 \%$ palm kernel cake.
\end{abstract}

Key words: Brachiaria brizantha, chemical composition, Elaeis guineensis Jacq

\section{Resumo}

Desenvolveu-se esse estudo com o objetivo de avaliar a qualidade da silagem de capim-piatã com torta de dendê (Elaeis guineensis Jacq.). O experimento foi conduzido no Instituto Federal Goiano, Campus Rio Verde. O delineamento experimental utilizado foi o inteiramente casualizado, com quatro tratamentos e cinco repetições. Os tratamentos foram compostos por capim-piatã ensilado com torta de dendê nos níveis de $0,5,10$ e 15\% com base na matéria natural do capim-piatã. O material foi picado, misturado, compactado em silos experimentais e abertos após 60 dias de fermentação. Os resultados demonstraram que o uso da torta de dendê é uma estratégia viável da utilização dos subprodutos agroindustriais, por enriquecer a silagem, proporcionando aumento no valor nutricional. A adição da torta de dendê melhorou os parâmetros fermentativos e bromatológicos da silagem, elevando os teores de matéria seca, proteína bruta, extrato etéreo e nutrientes digestíveis totais, com redução da fração fibrosa, valor de pH, nitrogênio amoniacal e acidez titulável. Esta diminuição proporcionou aumento das frações A, B1, B2 e digestibilidade in vitro da matéria seca e diminuição da fração B3 e C. Recomenda-se a adição do nível de $15 \%$ da torta de dendê, por proporcionar melhor qualidade da silagem.

Palavras-chave: Brachiaria brizantha, composição bromatológica, Elaeis guineensis Jacq

${ }^{1}$ Discente Instituto Federal Goiano, Campus Rio Verde, Rio Verde, GO, Brasil. E-mail: rangelisfigueredo@hotmail.com

${ }^{2}$ Prof $^{\text {as }}$ Pesquisadores, Instituto Federal Goiano, Campus Rio Verde, Rio Verde, GO, Brasil. E-mail: katiazoo@hotmail.com; katiacefetrv@hotmail.com; severianoec@yahoo.com.br

${ }_{3}^{3}$ Discentes Pós-graduação em Ciências Agrárias, IF Goiano, Campus Rio Verde, Rio Verde, GO, Brasil. E-mail: patyepifanio@ yahoo.com.br; welmacruvinel@hotmail.com

${ }^{4}$ Discente Pós-graduação em Nutrição e Produção Animal, Faculdade de Medicina Veterinária e Zootecnia, FMVZ, Pirassununga, SP, Brasil. E-mail: taina-bio@hotmail.com

* Author for correspondence 


\section{Introduction}

New cultivars of forage have arisen every day to meet the demand of the animal production system and farmer. The Embrapa Beef Cattle introduced into the market the Brachiaria brizantha BRS Piatã as alternative to diversify the forage (EMBRAPA GADO DE CORTE, 2008). Grasses cultivated under tropical conditions present high production in favorable periods to vegetative growth and sharp reduction in unfavorable periods. Usually there is a surplus of forage in the rainy season, between October and March in the Central West region, which should be preserved for later supply during drier periods (SANTOS; ZANINE; OLIVEIRA, 2006).

The need for low-cost food in ruminant diets has contributed to increase the search for new alternatives of forage plants to be ensiled (ÁVILA et al., 2003). The grass silage is a promising substitute, since it is made from a pasture already grown in the property. However, despite all the advantages, the high moisture content at cutting, the low content of soluble carbohydrates and the high buffering power of tropical grasses in general are factors that inhibit an appropriate fermentation, preventing the preparation of high quality silages (McDONALD; HENDERSON; HERON, 1991). These factors affect negatively the fermentation, hindering the rapid decrease in the $\mathrm{pH}$, enabling undesirable secondary fermentation (EVANGELISTA et al., 2004).

Some foods are required for silage enrichment, with possibility to use agroindustrial by-products. Among numerous options, stands out the palm kernel cake to improve the silage quality, by increasing the dry matter and contributing to a better quality of silage (OLIVEIRA et al., 2011).

The palm kernel cake resulting from the milling and extraction of oil to produce biodiesel or edible oil can be used in animal feeding, with adequate capacity to supply the nutritional requirements of ruminants (SILVA et al., 2005). However, there is little information about its effect on the fermentation and chemical characteristics of tropical grass silages. In this context, it was evaluated silage quality of Piata palisadegrass with palm kernel cake (Elaeis guineensis Jacq.).

\section{Material and Methods}

The experiment was carried out in the Federal Institute of Goiás State, Campus Rio Verde, at 748 $\mathrm{m}$ altitude, $17^{\circ} 48^{\prime} \mathrm{S}$ and $50^{\circ} 55^{\prime} \mathrm{W}$, from September 2010 to July 2011 . The pasture area used for silage production had $180 \mathrm{~m}^{2}$.

The soil was classified as distroferric Red Latosol (Oxisol), with $530 \mathrm{~g} \mathrm{~kg}^{-1}$ clay; $250 \mathrm{~g} \mathrm{~kg}^{-1}$ silt and $220 \mathrm{~g} \mathrm{~kg}^{-1}$ sand. Chemical characteristics of the soil before planting, at the $0-20 \mathrm{~cm}$ layer were: $\mathrm{pH}$ in water 5.6; Ca: $4.04 \mathrm{cmol}_{\mathrm{c}} \mathrm{dm}^{-3} ; \mathrm{Mg}: 2.0 \mathrm{cmol}_{\mathrm{c}}$ $\mathrm{dm}^{-3} ; \mathrm{Al}: 0.0 \mathrm{cmol}_{\mathrm{c}} \mathrm{dm}^{-3} ; \mathrm{Al}+\mathrm{H}: 6.6 \mathrm{cmol}_{\mathrm{c}} \mathrm{dm}^{-3} ; \mathrm{K}$ : $65 \mathrm{mg} \mathrm{dm}^{-3}$; CTC: $7.05 \mathrm{cmol}_{\mathrm{c}} \mathrm{dm}^{-3}$; P: $8.07 \mathrm{mg} \mathrm{dm}^{-3}$; $\mathrm{Cu}: 3.7 \mathrm{mg} \mathrm{dm}{ }^{-3}$; Zn: $1.8 \mathrm{mg} \mathrm{dm}^{-3}$; V: $48.4 \%$; M.O: $35.6 \mathrm{~g} \mathrm{~kg}^{-1}$.

The area was prepared with harrowing followed by leveling. At forage planting $80 \mathrm{~kg} \mathrm{ha}^{-1} \mathrm{P}_{2} \mathrm{O}_{5}$ was applied, using triple super phosphate as source. Then the Piata palisadegrass was broadcast seeded with $9 \mathrm{~kg}$ viable pure seeds per hectare. At the $40^{\text {th }}$ day after planting, the standardization cut was performed, followed by topdressing of $80 \mathrm{~kg} \mathrm{ha}^{-1}$ nitrogen and $40 \mathrm{~kg} \mathrm{ha}^{-1}$ potassium, in the sources of urea and potassium chloride, respectively.

The experimental design was completely randomized with four treatments and five repetitions. The treatments consisted of Piata palisadegrass ensiled with palm kernel cake at levels of $0,5,10$ and $15 \%$ on a natural basis of the Piata palisadegrass.

Before ensiling, the Piata palisadegrass and the palm kernel cake underwent a chemical analysis, as presented in the Table 1. 
Table 1. Chemical composition of Piata palisadegrass and palm kernel cake used for silage production.

\begin{tabular}{lcc}
\hline \multicolumn{1}{c}{ Chemical composition } & Piata palisadegrass & Palm kernel cake \\
\hline DM (\%) & 18.4 & 92.0 \\
CP (\%) & 12.5 & 16.3 \\
NDF (\%) & 68.3 & 65.2 \\
ADF (\%) & 39.5 & 34.4 \\
Lignin (\%) & 4.91 & 7.88 \\
Cellulose (\%) & 34.6 & 26.5 \\
Hemicellulose (\%) & 28.8 & 32.8 \\
EE (\%) & 2.35 & 6.80 \\
TDN (\%) & 59.4 & 62.6 \\
IVDMD (\%) & 62.5 & 69.5 \\
\hline
\end{tabular}

DM: dry matter; CP: crude protein; NDF: neutral detergent fiber; ADF: acid detergent fiber; EE: ether extract; TDN: total digestible nutrient; IVDMD: in vitro dry matter digestibility.

Source: Elaboration of the authors.

For ensiling, the Piata palisadegrass was harvested at 45 days after maintenance fertilization, $20 \mathrm{~cm}$ from the ground, using backpack brush cutter. The forage was minced using a stationary shredder into particles of $10-30 \mathrm{~mm}$ and ground. Then the material was homogenized with the palm kernel cake, according to the different levels set and stored in PVC experimental silos, with $10 \mathrm{~cm}$ diameter and $40 \mathrm{~cm}$ length.

The ensiled material was compacted with an iron pendulum and silos were closed with PVC caps and sealed with adhesive tape to prevent air inlet. Silos were kept at room temperature and protected from rain and sunlight.

After 60 days of fermentation, silos were opened, and discarded the top and bottom portions of each silos. The remaining material was homogenized and placed on plastic trays. A portion of the fresh silage after opening the silos was analyzed as for fermentation parameters, such as $\mathrm{pH}$, titratable acidity, and ammonia nitrogen in relation to the total nitrogen $\left(\mathrm{N}-\mathrm{NH}_{3} / \mathrm{TN}\right)$. The $\mathrm{pH}$ and titratable acidity was measured with a Beckman Expandomatic SS-2 potentiometer soon after opening the silos.

After this procedure, the silage was divided into two portions. The first was wrapped in plastic bags and frozen. In order to determine the ammonia nitrogen $\left[\mathrm{N}-\mathrm{NH}_{3}(\%\right.$ total $\left.\mathrm{N})\right]$, samples were thawed to extract the juice by pressing (AOAC, 1980). The other part with approximately $1 \mathrm{~kg}$ was weighed and dried in a forced air oven at $60-65^{\circ} \mathrm{C}$ for 96 hours to determine the pre-dried mass. Later, samples were ground in a Wiley type mill with $1 \mathrm{~mm}$ mesh sieve.

Chemical analyses determined the content of dry matter (DM), crude protein (CP), neutral detergent fiber (NDF), acid detergent fiber (ADF), lignin, cellulose, hemicellulose, ether extract (EE) and ash by the method described in Silva and Queiroz (2002). The percentage of total carbohydrates $(\mathrm{TCH})$ was estimated by the equation of Sniffen et al. (1992): $(\mathrm{TCH})=100-(\% \mathrm{CP}+\% \mathrm{EE}+\%$ ash $)$.

Non-protein nitrogen (NPN), neutral detergent insoluble nitrogen (NDIN) and acid detergent insoluble nitrogen (ADIN) were measured according to Licitra, Hernandez and Van Soest (1996), and soluble nitrogen, according to Krishnamoorthy et al. (1983).

The protein fractionation was calculated by the Cornell Net Carbohydrate and Protein System (SNIFFEN et al., 1992) and the protein was analyzed and calculated for the five fractions, A, B1, B2, B3 and $\mathrm{C}$. The in vitro dry matter digestibility (IVDMD) was determined by procedure of Tilley and Terry (1963), with two incubation stages of 48 hours.

Data were submitted to analysis of variance and regression, using the software SISVAR 4,6 (FERREIRA, 2000). 


\section{Results and Discussion}

Values of $\mathrm{pH}$, titratable acidity, $\mathrm{N}-\mathrm{NH}_{3} / \mathrm{TN}, \mathrm{DM}$, $\mathrm{CP}, \mathrm{NDF}, \mathrm{ADF}$, lignin, cellulose, EE, CHOT, protein fractionation (A, B1, B2, B3 and C) and IVDMD were significantly influenced $(\mathrm{P}<0.05)$ by addition of palm kernel cake into the Piata palisadegrass silage.

A linear reduction was observed for $\mathrm{pH}$ values with increasing levels of palm kernel in the Piata palisadegrass silage. The addition of $5 \%$ was effective to lower the $\mathrm{pH}$ value from 4.7 to 4.0 . At $10 \%$, the palm kernel cake resulted in reduction of 1.0 percentage unit relative to level zero, where the minimum point was estimated at $13.5 \%$, with minimum $\mathrm{pH}$ of 3.6 (Figure 1). These results evidenced the effectiveness of palm kernel cake in reducing the silage $\mathrm{pH}$, for containing high content of DM in relation to the Piata palisadegrass (Table 1). The highest $\mathrm{pH}$ value in the silage without additive is due to the lowest content of soluble carbohydrates in Brachiaria plants (COSTA et al., 2011).

The $\mathrm{pH}$ of a food is a main factor that determines the proliferation and spread of microrganisms, considered a parameter in the silage qualification (AMARAL et al., 2007). Tomich et al. (2004) observed that the $\mathrm{pH}$ range 3.8 to 4.2 is appropriate for a well preserved silage, because this range restricts proteolytic enzymes of the plant, enterobacteria and clostridiums, which lead to undesirable processes for a good fermentation.

Figure 1. Values of $\mathrm{pH}$ (a) and titratable acidity (b) of the Piata palisadegrass ensiled with different levels of palm kernel cake.

(a)

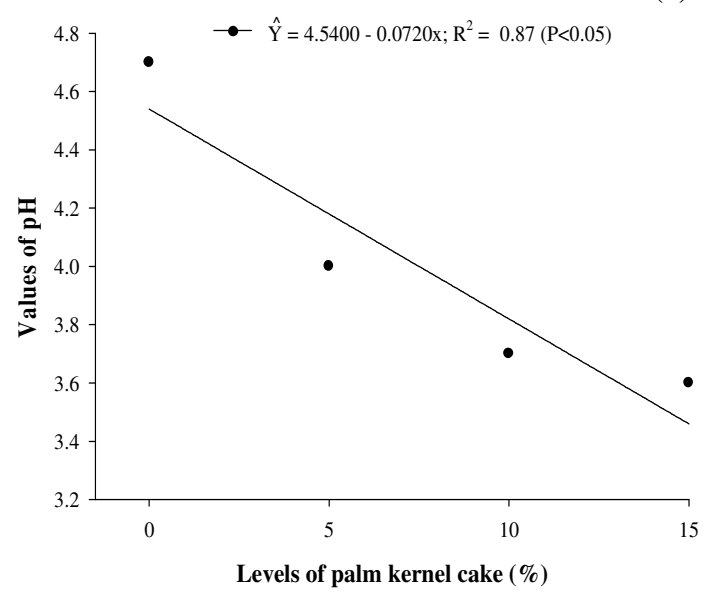

Source: Elaboration of the authors.

The Figure $1 \mathrm{~b}$ showed that titratable acidity had been affected by palm kernel cake levels, with a linear reduction according to its increased levels. The addition of $15 \%$ of palm kernel cake has decreased this variable in 4.7 percent relative to level zero. Silva and Queiroz (2002) argued that the titratable acidity indicates the general aspect of the silage fermentation quality, influencing the taste,

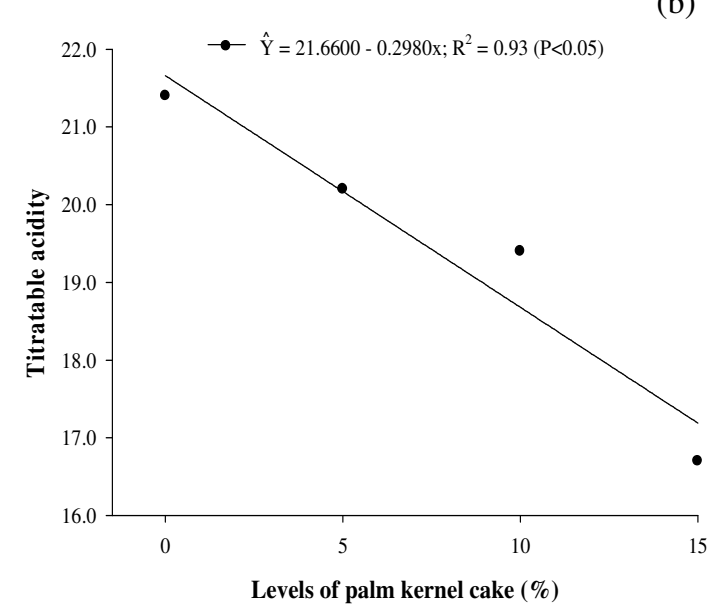

odor, color, and stability, for being directly related with acids that determine the $\mathrm{pH}$, especially lactic acid.

The ammonia nitrogen $\left(\mathrm{N}-\mathrm{NH}_{3} / \mathrm{TN}\right)$ also indicate the silage quality and helps in the characterization of the fermentation profile occurred in the process. The smaller $\mathrm{N}-\mathrm{NH}_{3} / \mathrm{TN}$ ratio, the lower the proteolysis of the ensiled material and better the silage quality 
(McDONALD; HENDERSON; HERON, 1991). A

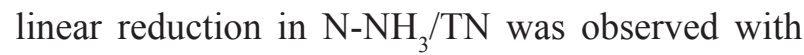
increased addition of palm kernel cake (Figure 2 a) with minimum point estimated at $14.3 \%$. The addition of highest level promoted a reduction of $3.97 \%$ in relation to the non-addition, indicating a decrease in crude protein degradation. This result is due to the higher content of $\mathrm{DM}$ and $\mathrm{pH}$ value in the level of $15 \%$, which can reduce the activity of bacteria such as Clostridium, which promote proteolysis and release of $\mathrm{N}_{-} \mathrm{NH}_{3} / \mathrm{TN}$ during the ensiling process (TEXEIRA et al., 2008). However, the highest content of $\mathrm{N}-\mathrm{NH}_{3} / \mathrm{TN}$ in the silage without palm kernel cake is associated with the lower content of readily fermentable carbohydrates, and DM, and the higher buffering capacity, typical of perennial forage grasses (LEONEL et al., 2009).

Even in the treatment without addition of palm kernel cake, the content of $\mathrm{N}-\mathrm{NH}_{3} / \mathrm{TN}$ is considered acceptable for the silage. The content remained below $10 \%$ indicating a good quality of silage considering this parameter, according to Tomich et al. (2004). Oliveira et al. (2010) found values of
$\mathrm{N}-\mathrm{NH}_{3} / \mathrm{TN}$ ranging from 2.4 to 5.8 , relative to the $1^{\text {st }}$ and $56^{\text {th }}$ fermentation day, respectively, when added $10 \%$ palm kernel cake in the silage of peach palm by-product.

There was a quadratic effect in the mineral matter content as increased the levels of palm kernel cake added to the silage, where the minimum point was estimated at the level of $12.4 \%$, with minimum values of $7.3 \%$ (Figure $2 b$ ). The level zero presented the highest content of mineral matter, due to the greater possibilities of losses by effluent in this treatment, with inadequate fermentation, and consequent losses of organic matter, increasing the relative participation of the ash (mineral matter) in the DM (ASHBELL, 1995).

Oliveira et al. (2011) examined the inclusion of palm kernel cake in Massai guineagrass silage, and verified a negative linear behavior of the mineral matter as a function of the levels of palm kernel cake in the silage, for every $1 \%$ inclusion, there was a reduction of 0.137 percent in the mineral matter.

Figure 2. Content of $\mathrm{N}^{-\mathrm{NH}_{3}} / \mathrm{TN}$ (a) and of mineral matter (b) of the Piata palisadegrass ensiled with levels of palm kernel cake.

(a)

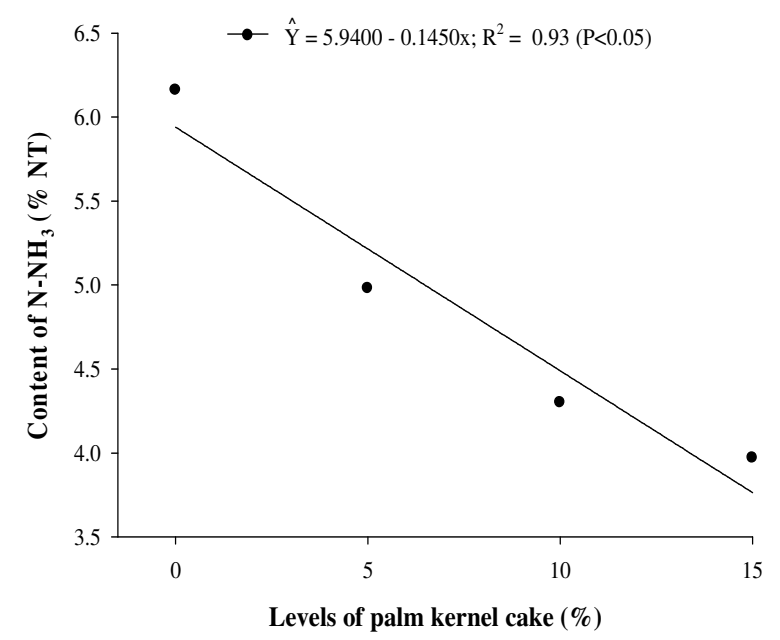

(b)

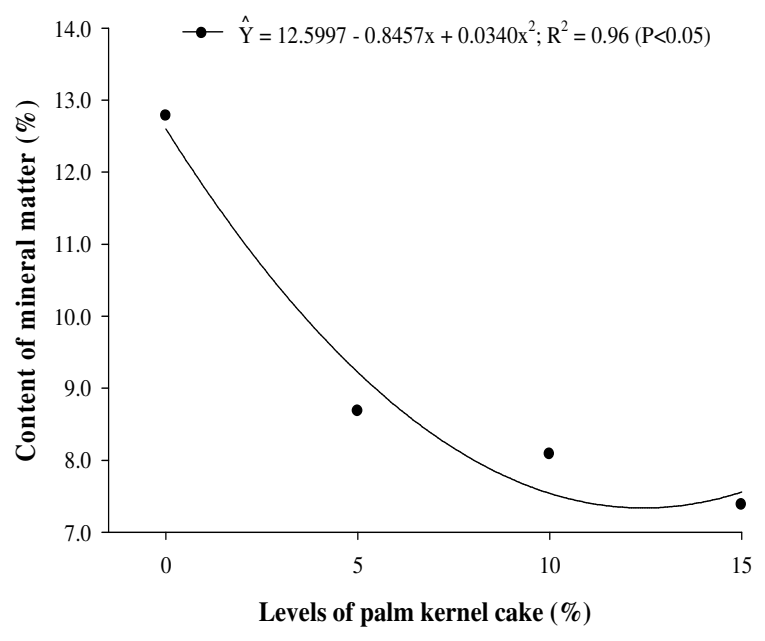

Source: Elaboration of the authors. 
The Figure 3 illustrates that the palm kernel cake promoted a positive linear increase in the DM content of the silage. The level of $15 \%$ was sufficient to increase the DM content from 16.5 to $25.2 \%$, resulting in an increase of $52.7 \%$ in the DM content of the silage. This result indicated that the palm kernel cake helped in the fermentation process, by reducing the effluents draining from ensiled mass, preventing the development of microorganisms undesirable to the fermentation (PEREIRA; REIS, 2001).

The Massai guineagrass silage with levels of 0 , 8,16 and $24 \%$ of palm kernel cake from biodiesel production presented a linear increase in the DM content of silage from 22.3 to $38.1 \%$ at the level zero to $24 \%$, respectively (OLIVEIRA et al., 2011). These values emphasize the importance of using palm kernel cake in animal nutrition, and prove its efficiency in the moisture retention process.

Figure 3. Content of dry matter (DM) (a) and crude protein (CP) (b) of the Piata palisadegrass ensiled with levels of palm kernel cake.

(a)

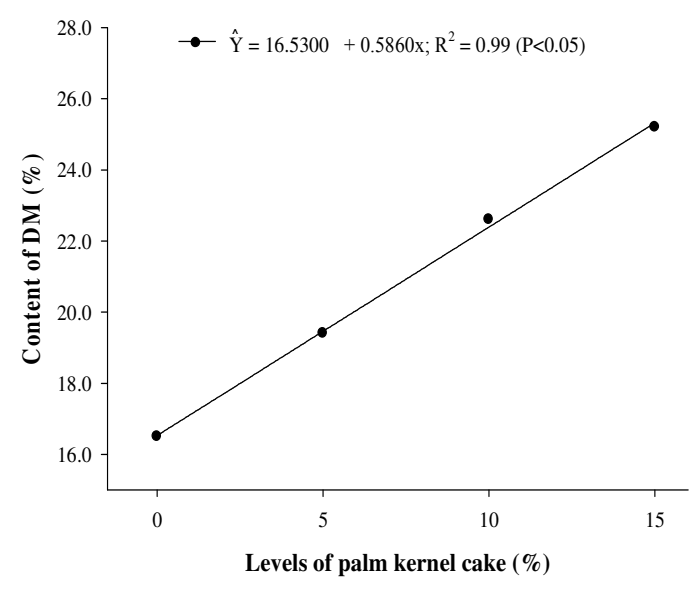

Source: Elaboration of the authors.

A linear increase was observed for CP content with increasing levels of palm kernel cake (Figure $3 \mathrm{~b})$. The addition of $15 \%$ resulted in CP content of $13.6 \%$, showing an increase of $91.5 \%$ in relation to the non-addition. This can be because the palm kernel cake has a greater $\mathrm{CP}$ content than Piata palisadegrass (Table 1) and the inclusion improved the silage quality. Moreover, the greater DM content in the palm kernel cake, especially at $15 \%$, restricts the activity of Clostridium, preserving the protein fraction of the forage (AGUIAR et al., 2001).

The silage fermentation process with agroindustrial by-products of the extraction of fresh peach palm added with palm kernel was analyzed by Oliveira et al. (2010), and showed an increase of $7.79 \%$ in the content of CP of silage, and can be an option for ruminants feeding.

Evaluating NDF and ADF content in the different levels (Figure $4 \mathrm{a}$ and $4 \mathrm{~b}$ ), the palm kernel cake contributed to reduce the fiber fraction of the Piata palisadegrass silage. Although the palm kernel had presented fiber content similar to the Piata palisadegrass, the addition of $15 \%$ resulted in a reduction of $4.84 \%$ in NDF content and of $10.2 \%$ in the ADF, in comparison with the non-addition. These results are important once according to Van Soest (1994), the NDF and ADF content are negatively correlated with the intake and 
digestibility, respectively, allowing the inference that the addition of palm kernel cake brings benefits, by reducing fiber fraction, promoting better conditions for the intake and digestibility of the Piata palisadegrass silage. Costa et al. (2010) verified that the supply of palm kernel cake up to the level of $30 \%$ of inclusion into the total diet of sheep improves the ADF digestibility coefficient.

Figure 4. Content of neutral detergent fiber (NDF) (a) and acid detergent fiber (ADF) (b) of the Piata palisadegrass ensiled with levels of palm kernel cake.

(a)

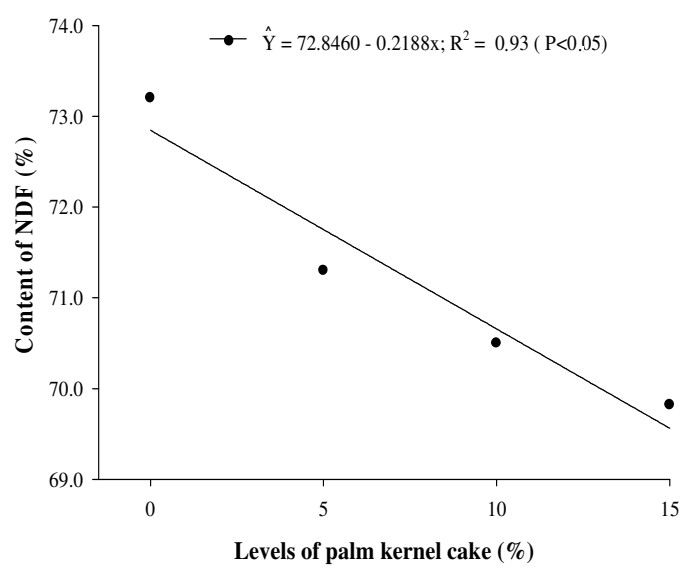

Source: Elaboration of the authors.

Lignin and cellulose content were also influenced by the levels of palm kernel cake in the silage of Piata palisadegrass. However, a linear increase in the lignin content was registered with increasing levels of palm kernel cake (Figura 5a), with increase of $18.1 \%$ in relation to the level zero. This is due to the higher lignin content of the palm kernel relative to Piata palisadegrass, which present thin stem and produce forage with better quality, due to the high leaf:stem ratio (EMBRAPA GADO DE CORTE, 2007).

Oliveira et al. (2010) when used Massai guineagrass ensiled with palm kernel cake, observed lignin content of $13.09 ; 13.35 ; 14.66$ and $13.07 \%$ for levels of $0,8,16$ and $24 \%$, respectively. These values were higher than found here for Piata palisadegrass silage.

In relation to the cellulose, a linear reduction was detected with increasing levels of addition of palm kernel (Figure 5b). The cellulose content obtained with the addition of $15 \%$ was $35.0 \%$, a reduction of $13.9 \%$ in relation to the non-addition. Van Soest (1994) explained that the cellulose represents greatest important component in the cell wall structure, its nutritional availability varies from indigestible to completely digestible, depending on the lignification degree. Even with variation between the levels within each additive, the present study showed that the cellulose content remained between 20 and $40 \%$ of DM, as recommended by Van Soest (1994) for tropical forages.

Oliveira et al. (2010) investigated the silage of fresh peach palm supplemented with cassava meal, corn meal, palm kernel cake and urea, and verified that the palm kernel cake did not increase the cellulose content, since its concentration in the byproduct is higher than in the palm kernel. 
Figure 5. Content of lignin (a) and cellulose (b) of the Piata palisadegrass ensiled with levels of palm kernel cake.

(a)
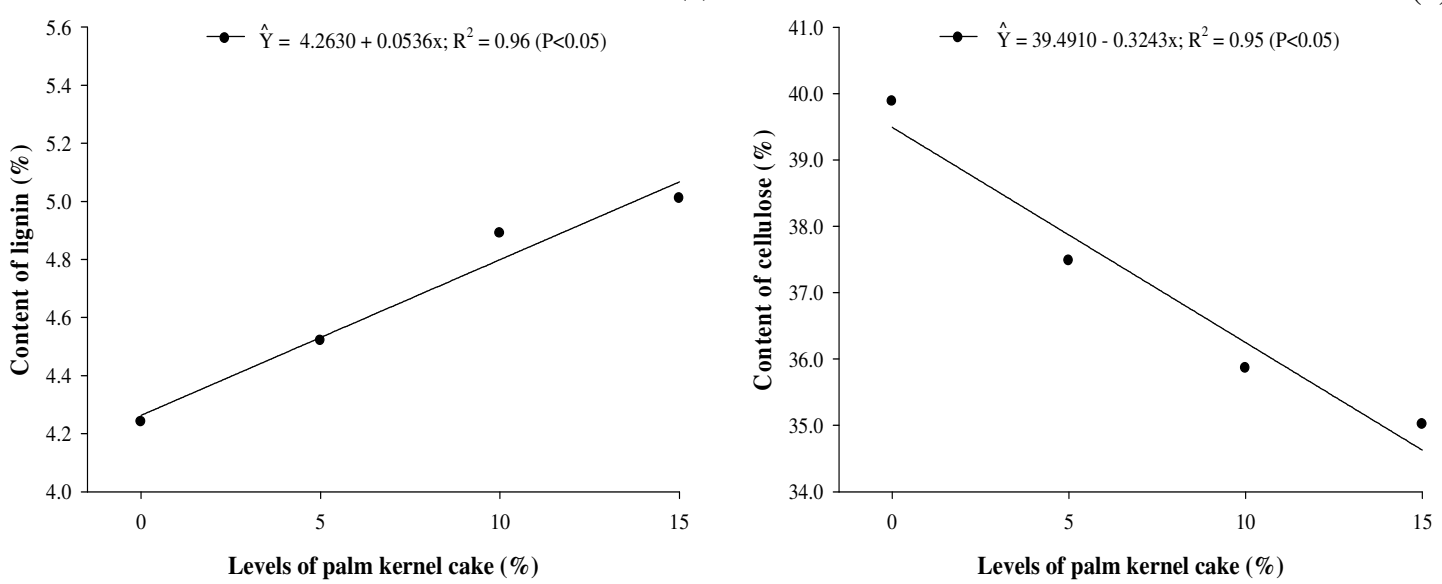

Source: Elaboration of the authors.

The Figure 6a demonstrates the results of EE, according the addition of palm kernel cake led to a positive linear effect, with an increase of 3.85 percentage units in relation the level zero. This increase is justified by higher EE content of palm kernel cake (Table 1). Nunes et al. (2011) reported that the palm oil extraction is a physical process and the generated by-product contains considerable amount of EE.

Rezende et al. (2002) evaluated the nutritional value of elephant grass ensiled with sunflower addition, and observed that the silage mixed with sunflower had greater EE content than observed in the elephant grass silage, which can be explained by sunflower seeds presence in the silage, with higher levels of mixture.

Regardless of palm kernel cake levels, in the present study, EE content did not exceed $6-7 \%$ of DM. According to NRC (2001), the total fat in the diet should not surpass these values, since it can lead to reductions in ruminal fermentation, fiber digestibility, and passage rate.

Figure 6. Content of ether extract (a) and total carbohydrate (b) of the Piata palisadegrass ensiled with levels of palm kernel cake.

(a)

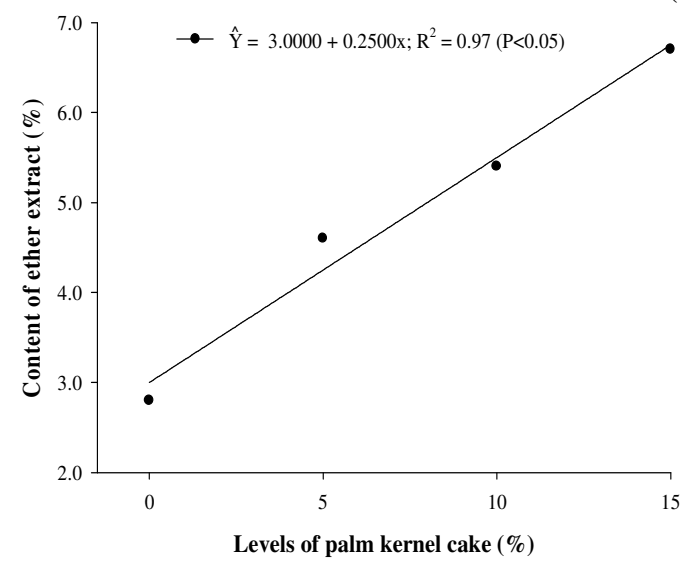

(b)

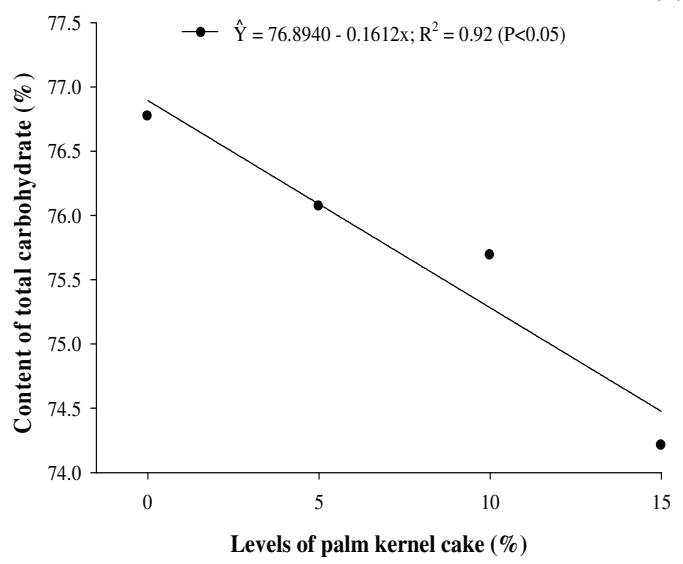

Source: Elaboration of the authors. 
The addition of palm kernel cake promoted a linear decrease in the total carbohydrate (TCHO) content (Figure 6b). This result is related to the higher CP and EE content at the level of $15 \%$. Sniffen et al. (1992) reported that great contents of $\mathrm{CP}$ and EE can reduce carbohydrate content.

Carvalho, Garcia and Pires (2007) studied elephant grass ensiled with cocoa meal and observed a linear decrease in the TCHO content, with a reduction of 0.22 percent to every unit of meal added. The same was observed by Andrade et al. (2010) with the elephant grass silage containing cassava meal, coffee husk and cocoa meal, with a reduction of $9.21 \%$ of the cocoa meal in relation to the other food.

Considering the fraction A, the Figure 7a shows a linear increase with increasing levels of palm kernel cake in the silage. The level of $15 \%$ was most effective to increase this fraction in the silage, showing an increase of $45.6 \%$ relative to the level zero. This result is important, because the fraction A is considered a soluble fraction with rapid ruminal degradation. This, due to the higher CP content in the kernel $(16.3 \%)$ in relation to the Piata palisadegrass (12.5\%), improving degradation rate. According to Russell et al. (1992), sources of non-protein nitrogen (NPN) are essential for a proper functioning of the rumen, because the ruminal microorganisms, fermenting structural carbohydrates, use ammonia as a nitrogen source.

Andrade et al. (2010) investigated the elephant grass silage containing cassava meal, coffee husk and cocoa meal, and verified a decreasing linear effect according to inclusion of different meals. In agreement with the authors, this occurred owing the low content of dry matter (18.7\%) which interfered with the degradable protein availability.

Figure 7. Fraction A (a) and B1 (b) of the Piata palisadegrass ensiled with levels of palm kernel cake.

(a)

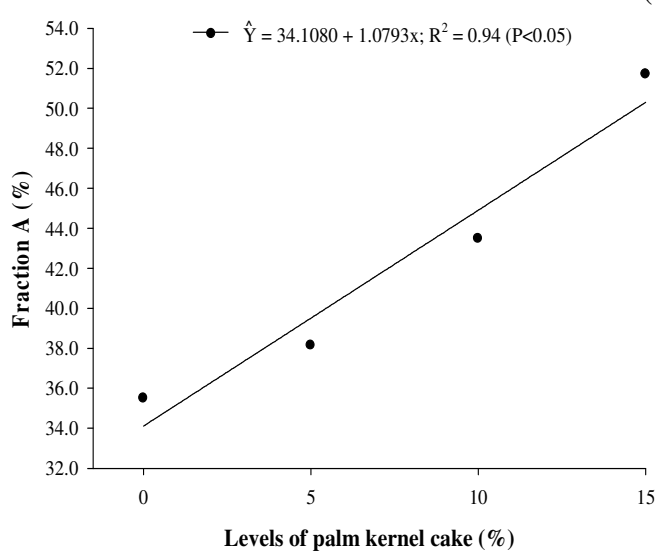

Source: Elaboration of the authors.

For fraction B1, there was a linear increase (Figure $7 b$ ) with the addition of palm kernel cake to the silage. The highest fraction B1 was obtained at level of $15 \%$, with increase of $33.5 \%$ when compared with the level zero. Given this, it is important to emphasize that the participation of $15 \%$ of palm

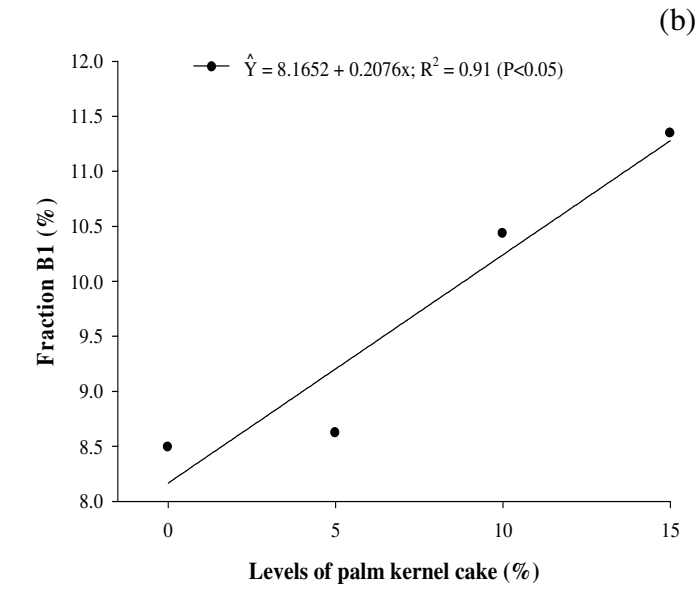

kernel cake in the silage of Piata palisadegrass increases the fraction B1, bringing benefits for a better ruminal degradation, since it can ensure a better synchronism between the fermentation of carbohydrates and protein in the rumen and, consequently improve the microbial growth, 
resulting in better use of nutrients (PEREIRA et al., 2010). These results are relevant since the fraction B1 is also a soluble fraction with rapid degradation in the rumen (SNIFFEN et al., 1992).

A linear increase of the fraction B2 was observed with increasing addition of palm kernel cake in the silage (Figure 8a). When compared level zero with the level of $15 \%$, there was an increase of $38.0 \%$ in the fraction $\mathrm{B} 2$. The fraction $\mathrm{B} 1+\mathrm{B} 2$, by having rapid ruminal degradation rate in relation to the fraction $\mathrm{B} 3$, tend to be extensively degraded in the rumen, helping to meet the nitrogen requirements of ruminal microorganisms, but the rapid proteolysis these fractions in the rumen may lead to peptides accumulation and allow their escape into the intestines, once the use of peptides is limiting for protein degradation (SNIFFEN et al., 1992).
The values of fraction B2 varied between 10.8\% for level zero and $14.9 \%$ for level 15\%. Epifanio et al. (2014) evaluated the protein fractionation of Piata palisadegrass ensiled with different meals from the biodiesel industry byproducts and verified values of fraction B2 of $14.69 ; 15.94 ; 14.97$ and $14.62 \%$ for cotton, sunflower, soybean and canola meals, respectively. These values were similar to obtained in the present study.

The Fraction B3 has a very slow degradation rate, since it is associated with the plant cell wall. This fraction is represented by proteins bound to cell wall, therefore it presents a slow degradation rate, being primarily digested in the intestine (BALSALOBRE et al., 2003).

Figure 8. Fraction B2 (a) and B3 (b) of the Piata palisadegrass ensiled with levels of palm kernel cake.

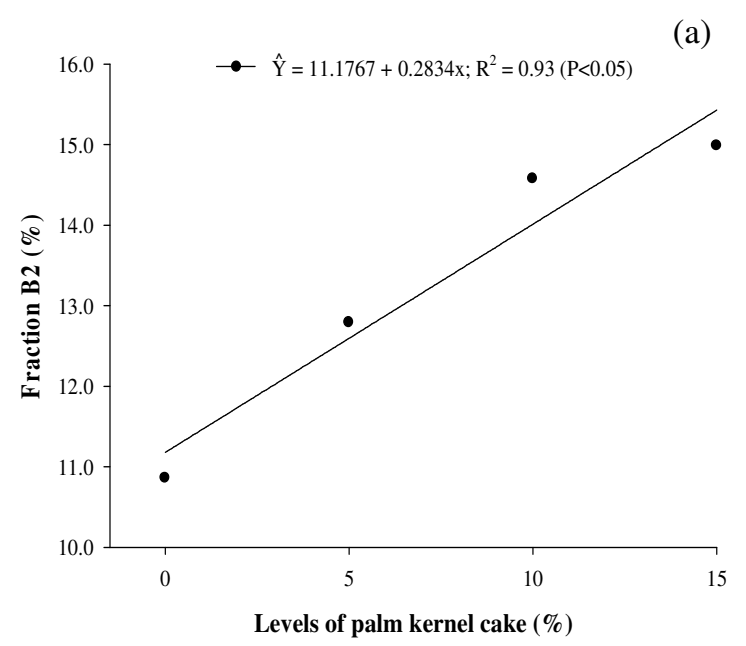

Source: Elaboration of the authors.

The addition of palm kernel cake promoted a linear reduction of the fraction B3 with increasing levels in the silage (Figure 8b), whose reduction at the level $15 \%$ was $91.7 \%$ compared with the level zero. This result is ascribed to the lower content of $\mathrm{CP}$ of the Piata palisadegrass, thus greater fractions B3 were obtained in the control silage, with slower degradation. As the fraction B3 is represented by

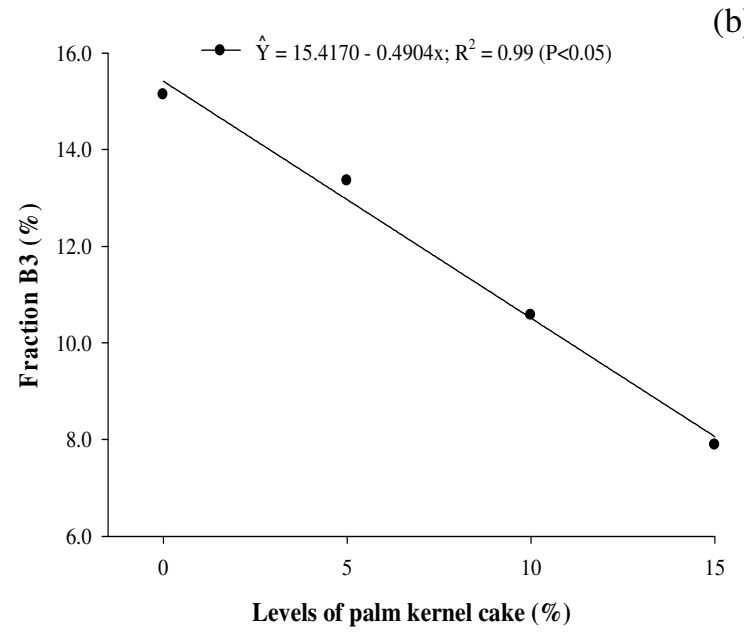

binding proteins of the cell wall that present slow degradation rate, being primarily digested in the intestine (CABRAL et al., 2004), it is possible that non-addition of palm kernel cake in the Piata palisadegrass silage increases the undegraded protein in the rumen, once higher values of B3 and sharp reduction in the fraction $\mathrm{A}$ were observed in the control silage. 
Pires, Carvalho and Garcia (2009) examined the protein fractionation of elephant grass silage and observed values of fraction B3 of 10.7; 11.6; 21.5 and $19.5 \%$ for control silage, and silage added with coffee husk, cocoa meal, and cassava meal, respectively.

In relation to the fraction $\mathrm{C}$, a linear decrease of this fraction was observed according to increasing levels of palm kernel in the silage, with a reduction of $106.6 \%$ comparing the level zero and the level $15 \%$ (Figure 9a). This result is noteworthy once the fraction $\mathrm{C}$ corresponds to the unavailable nitrogen, and consists of protein and nitrogen compounds associated with lignin (SNIFFEN et al., 1992; VAN SOEST, 1994). Krishnamoorthy et al. (1983) argued that this fraction cannot be degraded by ruminal bacteria and does not provide amino acids for postruminal digestion. This shows that an expressive part of the silage protein is not used for microbial growth or even as a real source of protein in the post-ruminal digestive tract.
The results found in the present experiment are satisfactory as for the silage that received palm kernel cake, once according to Sniffen et al. (1992), the increase in the fraction C is complicated by the formation of Maillard products caused by the heating inside the silo, and by undesirable fermentation derived from the high moisture content of the forage. In this case, the reduction of fraction $\mathrm{C}$ under palm kernel cake inclusion, mainly at the level $15 \%$, can be attributed to the palm kernel cake quality, considered a good food for the ensiling process.

Carvalho et al. (2008) studied the protein fractionation of elephant grass ensiled with cocoa meal, and observed a quadratic behavior for fraction $\mathrm{C}$ as a function of the levels of cocoa meal, estimating the maximum value at $33.0 \%$ for the level of $19.6 \%$.

Figure 9. Fraction C (a) and in vitro dry matter digestibility (b) of the Piata palisadegrass ensiled with levels of palm kernel cake.

(a)

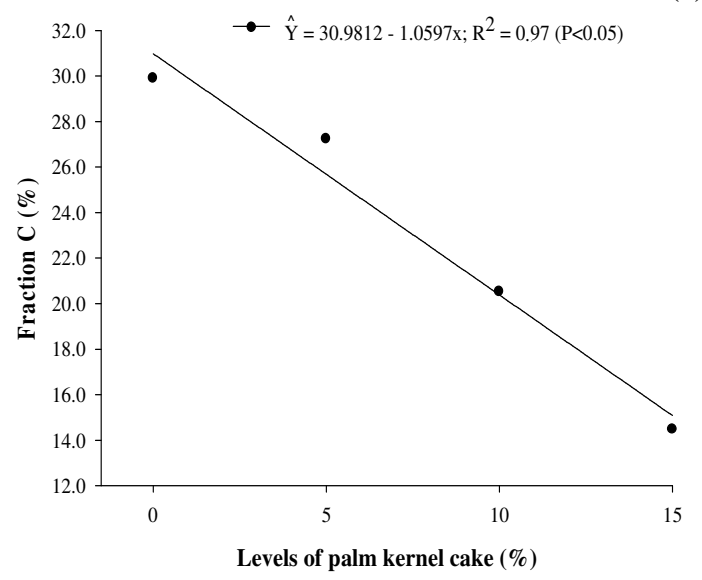

Source: Elaboration of the authors.

The results of in vitro dry matter digestibility (IVDMD) is presented in the Figure 9b, showing a linear increase in the digestibility with increasing levels of palm kernel cake, showing that this inclusion promote a greater digestibility of the DM. This enhanced digestibility is probably associated with changes in chemical composition of the fraction with decreasing NDF, ADF, and 
cellulose content, which certainly make available the readily digestible carbohydrates for ruminal microorganisms (FERNANDES et al., 2002).

Costa et al. (2010), working with intake and digestibility of diets with different levels of palm kernel cake for sheep, observed that this cake can be used up to level of $30 \%$ in the total diet, improving the digestibility of acid detergent fiber. Rodrigues et al. (2007) studied the elephant grass ensiled with citrus pulp and detected a linear increase of the IVDMD with increasing levels citrus pulp in the silage.

In this way, the use of palm kernel cake contributed with an adequate preservation of the evaluated silage, balancing the fermentation parameters, and promoting quality to the ensiled material. The results were satisfactory for all evaluated variables, confirming that the use of palm kernel cake in the Piata palisadegrass silage is a viable solution for using this by-product.

\section{Conclusions}

The inclusion of palm kernel cake improve the fermentation and chemical parameters of the Piata palisadegrass silage, and increase dry matter, crude protein and ether extract content, with a simultaneous reduction in fiber fraction, $\mathrm{pH}$, ammonia nitrogen and titratable acidity. The use of palm kernel cake in Piata palisadegrass silage promote an increase of fractions A, B1, B2 and in vitro dry matter digestibility.

Under the studied conditions, the addition of $15 \%$ of palm kernel cake is recommended, since it provide the best quality Piata palisadegrass silage.

\section{References}

AGUIAR, R. N. S.; CRESTANA, R. F.; BALSALOBRE, M. A. A. Efeito do tamanho de partícula na composição da fração nitrogenada de silagem de capim Tanzânia. In: REUNIÃO ANUAL DA SOCIEDADE BRASILEIRA DE ZOOTECNIA, 38., Piracicaba, 2001. Anais... Piracicaba: FEALQ, 2001. p. 314-316.
AMARAL, R. C.; BERNADES, T. F.; SIQUEIRA, G. R.; REIS, R. A. Características fermentativas e químicas de silagens de capim-Marandu produzidas com quatro pressões de compactação. Revista Brasileira de Zootecnia, Viçosa, v. 36, n. 3, p. 532-539, 2007.

ANDRADE, I. V. A. O.; PIRES, A. J. V.; CARVALHO, G. G. P.; VELOSO, C. M.; BONOMO, P. Fracionamento de proteína e carboidratos em silagens de capim-elefante contendo subprodutos agrícolas. Revista Brasileira de Zootecnia, Viçosa, v. 39, n. 11, p. 2342-2348. 2010.

ASSOCIATION OFFICIAL ANALYTICAL CHEMISTS - AOAC. Official methods of analysis. 13. ed. Washington: AOAC, 1980. 1015 p.

ASHBELL, G. Basic principles of preservation of forage, by-products and residues as silage or hay. Bet Dagan: Agricultural Research Organization, The Volcani Center. 1995. $58 \mathrm{p}$.

ÁVILA, C. L. S.; PINTO, J. C.; EVANGELISTA, A. R.; MORAIS, A. R.; FIGUEIREDO, H. C. P.; TAVARES, V.B. Perfil de fermentação das silagens de capimTanzânia com aditivos - teores de nitrogênio amoniacal e pH. Ciências Agrotecnologia, Lavras, v. 27, n. 5, p. 11441151, 2003.

BALSALOBRE, M. A. A.; CORSI, M.; SANTOS, P. M.; VIEIRA, I.; CÁRDENAS, R. R. Composição química e fracionamento do nitrogênio e dos carboidratos do capim-tanzânia irrigado sob três níveis de resíduo póspastejo. Revista Brasileira de Zootecnia, Viçosa, v. 32, n. 3, p. 519-528, 2003.

CABRAL, L. S.; VALADARES FILHO, S. C.; DETMANN, E.; ZERVOUDAKIS, J. T.; VELOSO, R. G.; NUNES, P. M. M. Taxas de digestão das frações protéicas e de carboidratos para as silagens de milho e de capim-elefante, o feno de capim-tifiton-85 e o farelo de soja. Revista Brasileira de Zootecnia, Viçosa, v. 33, n. 6, p. 1573-1580, 2004.

CARVALHO, G. G. P.; GARCIA, R.; PIRES, A. J. V. Valor nutritivo de silagens de capim-elefante emurchecido ou com adição de farelo de cacau. Revista Brasileira de Zootecnia, Viçosa, v. 36, n. 5, p. 1495-1501, 2007.

CARVAlHO, G. G. P.; GARCIA, R.; PIRES, A. J. V.; PEREIRA, O. G.; FERNANDES, F. Ė. P.; CECON, P. R.; AZEVEDO, J. A. G. Fracionamento de proteínas de silagem de capim-elefante emurchecido ou com farelo de cacau. Ciência Animal Brasileira, Goiânia, v. 9, n. 3, p. 648-656, 2008.

COSTA, D. A.; FERREIRA, G. D. G.; ARAÚJO, C. V.; COLODO, J. C. N.; MOREIRA, R. G.; FIGUEIREDO, M. R. P. Consumo e digestibilidade de dietas com níveis 
de torta de dendê para ovinos. Revista Brasileira de Saúde Produção Animal, Salvador, v. 11, n. 3, p. 783792, 2010.

COSTA, K. A. P.; ASSIS, R. L.; GUIMARÃES, K. C.; SEVERIANO, E. C.; ASSIS NETO, J. M.; CRUNIVEL, W. S.; GARCIA J. F.; SANTOS, N. F. Silage quality of Brachiaria brizantha cultivars ensiled with different levels of millet meal. Arquivo Brasileiro de Medicina Veterinária e Zootecnia, Belo Horizonte, v. 63, n. 1, p. 188-195, 2011.

EMBRAPA GADO DE CORTE. Empresa Brasileira de Pesquisa Agropecuária. "Capim-piatã" homenageia povo indígena Tupi Guarani. Informativo Piatã, 2008.

Empresa Brasileira de Pesquisa Agropecuária. Piatã é o novo capim lançado pela Embrapa. 2007. Disponível em: <http://www.cnpgc.embrapa.br/index. php?pagina $=$ bancodenoticias $/ 15052007$ piata.htm $>$. Acesso em: 28 jul. 2012.

EPIFANIO, P.S.; COSTA, K.A.P.; SEVERIANO, E.C.; CRUVINEL, W.S.; BENTO, J.C.; PERIM, R.C. Fermentative and bromatological characteristics of Piata palisadegrass ensiled with levels of meals from biodiesel industry. Semina: Ciências Agrárias, Londrina, v. 35, n. 1, p. 491-504, 2014.

EVANGELISTA, A. R.; ABREU, J. G.; AMARAL, P. N. C.; PEREIRA, R. C.; SALVADOR, F. M.; SANTANA, R. A. V. Produção de silagem de capim-marandu (Brachiaria brizantha stapf cv. Marandu) com e sem emurchecimento. Ciência e Agrotecnologia, Lavras, v. 28, n. 2, p. 443-449, 2004.

FERNANDES, L. O.; REIS, R. A.; RODRIGUES, L. R. A. de; LUDIC, I. L; MANZAN, R. J. Qualidade do feno de braquiária decumbens stapf. submetido ao tratamento com amônia anidra ou uréia. Revista Brasileira de Zootecnia, Viçosa, v. 31, n. 3, p. 1325-1332, 2002.

FERREIRA, D. F. Análises estatísticas por meio do Sisvar para Windows versão 4.0. In: REUNIÃO ANUAL DA REGIÃO BRASILEIRA DA SOCIEDADE INTERNACIONAL DE BIOMETRIA, 45., 2000, São Carlos. Anais... São Carlos: UFSCar, 2000. p. 255-258.

KRISHNAMOORTHY, U.; SNIFFEN, C. J.; STERN, M. D.; VAN SOEST, P. J. Evaluation of a mathematical model of rumen digestion and an in vitro simulation of rumen proteolysis to estimate the rumen-undegraded nitrogen content of feedstuffs. British Journal of Nutrition, Oxford, v. 50, n. 3, p. 555-568, 1983.

LEONEL, F .P. L.; PEREIRA, J. C.; COSTA, M. G.; MARCO JÚNIOR, P.; DA SILVA, C. J.; LARA, L. A. Consórcio capim-braquiária e milho: comportamento produtivo das culturas e características nutricionais e qualitativas das silagens. Revista Brasileira de Zootecnia, Viçosa, v. 38, n. 1, p. 166-176, 2009.

LICITRA, G.; HERNANDEZ, T. M.; VAN SOEST, P. J. Standardization of procedures for nitrogen fractionation of ruminant feeds. Animal Feed Science and Technology, Amsterdam, v. 57, n. 4, p. 347-358, 1996.

McDONALD, P.; HENDERSON, A. R.; HERON, S. J. E. The biochemistry of silage. 2. ed. Marlow: Chalcombe Pub, 1991. 340 p.

NATIONAL RESEARCH COUNCIL - NRC. Nutrient requirements of dairy cattle. 7. ed. rev. Washinton, D.C.: 2001. 381 p.

NUNES, A. S.; OLIVEIRA, R. L.; BORJA, M. S.; BAGALDO, A. R.; MACOME, F. M.; JESUS, I. B.; SILVA, T. M.; BARBOSA, L. P.; GARCEZ NETO, A. F. Consumo, digestibilidade e parâmetros sanguíneos de cordeiros submetidos a dietas com torta de dendê. Archivos de Zootecnia, Córdoba, v. 60, n. 232, p. 903912, 2011.

OLIVEIRA, L. S.; PEREIRA, L. G. R.; AZEVEDO, J. A. G.; PEDREIRA, M. S.; LOURES, D. R. S.; BOMFIM, M. A. D.; BARREIROS, D. C.; BRITO, R. L. L. Caracterização nutricional de silagens do coproduto da pupunha. Revista Brasileira Saúde Produção Animal, Salvador, v. 11, n. 2, p. 426-439, 2010.

OLIVEIRA, R. L.; RIBEIRO, O. L.; BAGALDO, A. R.; LIMA, L. S.; BORJA, M. S.; CORREIA, B. R.; COSTA, J. B.; LEÃO, A. G. Torta de dendê oriunda da produção do biodiesel na ensilagem de capim-massai. Revista Brasileira de Saúde e Produção Aninal, Salvador, v. 12, n. 4, p. 881-892, 2011.

PEREIRA, E. S.; PIMENTEL, P. G.; DUARTE, L. S.; MIZUBUTI, I. Y.; ARAÚJO, G. G. L.; CARNEIRO, M. S. S.; REGADAS FILHO, J. G. L.; MAIA, I. S. G. Determinação das frações protéicas e de carboidratos e estimativa do valor energético de forrageiras e subprodutos da agroindústria produzidos no Nordeste Brasileiro. Semina: Ciências Agrárias, Londrina, v. 31, n. 4, p. 1079-1094, 2010.

PEREIRA, J. R. A.; REIS, R. A. Produção de silagem pré-secada com forrageiras temperadas e tropicais. In: SIMPÓSIO SOBRE PRODUÇÃO E UTILIZAÇÃO DE FORRAGENS CONSERVADAS, 2001, Maringá. Anais... Maringá: Universidade Estadual de Maringá, 2001. p. 64-86.

PIRES, A. J. V.; CARVALHO, G. G. P.; GARCIA, R. Fracionamento de carboidratos e proteínas de silagens de capim-elefante com casca de café, farelo de cacau ou farelo de mandioca. Revista Brasileira de Zootecnia, Viçosa, v. 38, n. 3, p. 422-427, 2009. 
REZENDE, A. V.; EVANGELISTA, A. R.; BARCELOS, A. F.; SIQUEIRA, G. R.; SANTOS, R. V.; MAZO, M. S. Efeito da mistura da planta de girassol (Helianthus annuus L. ), durante a ensilagem do capim-elefante (Pennisetum purpureum Schum.) no valor nutritivo da silagem. Revista Brasileira de Zootecnia, Viçosa, v. 31, n. 5, p. 1938-1943, 2002.

RODRIGUES, P. H. M.; LOBO, J. R.; SILVA, E. J. A.; BORGES, L. F. O.; MEYER, P. M.; DEMARCHI, J. J. A. A. Efeito da inclusão de polpa cítrica peletizada na confecção de silagem de capim-elefante (Pennisetum purpureum, Schum.). Revista Brasileira de Zootecnia, Viçosa, v. 36, n. 6, p. 1751-1760, 2007.

RUSSELL, B. J.; O'CONNOR, J. D.; FOX, D. J.; SOEST, P. J.; VAN SNIFFEN, C. J. A net carbohydrate and protein system for evaluation cattle diets: ruminal fermentation. Journal of Dairy Science, Champaign, v. 70, n. 12, p. 3551-3581, 1992.

SANTOS, E. M.; ZANINE, A. M.; OLIVEIRA, J. S. Produção de silagem de gramíneas tropicais. Revista Electrónica de Veterinária - REDVET, Espanha, v. 7, n. 7, p. 1-16, 2006.

SILVA, D. J.; QUEIROZ, A. C. Análise de alimentos: métodos químicos e biológicos. 3. ed. Viçosa: Imprensa Universitária da UFV, 2002. 235 p.
SILVA, H. G. O.; PIRES, A. J. V.; SILVA, F. F.; VELOSO, C. M.; CARVALHO, G. G. P., CEZÁRIO, A. S.; SANTOS, C. C. Farelo de cacau (Theobroma cação L.) e torta de dendê (Elaeis guineensis, Jacq) na alimentação de cabras em lactação: consumo e produção de leite. Revista Brasileira de Zootecnia, Viçosa, v. 34, p. 1790-1798, 2005.

SNIFFEN, C. J.; O'CONNOR, D. J.; VAN SOEST, P. J.; FOX, D. G.; RUSSELL, J. B. A net carbohydrate and protein system for evaluating cattle diets: carbohydrate and protein availability. Journal of Animal Science, Champaign, v. 70, n. 12, p. 3562-3577, 1992.

TILLEY, J. M. A.; TERRY, R. A. A two stage technique for in vitro digestion of forages crops. Journal of the British Grassland Society, Britannia, v. 18, n. 2, p. 104111, 1963.

TOMICH, T. R.; RODRIGUES, J. A. S.; TOMICH, R. G. P.; GONÇALVES, L. C.; BORGES, I. Potencial forrageiro de híbridos de sorgo com capim-sudão. Arquivos Brasileiros de Medicina Veterinária e Zootecnia, Belo Horizonte, v. 56, n. 2, p. 258-263, 2004.

VAN SOEST, P. J. Nutritional ecology of the ruminant. 2. ed. Ithaca: Cornell University Press, 1994. 476 p. 